\title{
Sprawozdanie z wyjazdu do Archiwum Instytutu im. gen. Sikorskiego w Londynie w 2017 r.
}

W trakcie zeszłorocznego wyjazdu do Londynu (6 tygodni, 13 listopada - 22 grudnia 2017 r.) kontynuowane były prace przy porządkowaniu materiałów archiwalnych. Zajmowałem się dalej wyłącznie aktami zidentyfikowanymi jako rozkazy.

Grupa akt określanych jako „Rozkazy” to wydzielona jednorodna część zasobu. Akta wchodzące w jej skład stanowią wyłącznie rozkazy pisemne normujące codzienny tok służby poszczególnych oddziałów, pododdziałów Polskich Sił Zbrojnych, różnych placówek czy oddziałów Polskiego Korpusu Przysposobienia i Rozmieszczenia. Struktura tych akt jest dość prosta - rozkazy dla konkretnych oddziałów to kolejne jednostki (mogą się jeszcze dzielić na lata, ale może też taka jednostka obejmować kilka roczników - najczęściej wtedy dokumenty złączone są w jednym oprawnym tomie). Od wielkości oddziału czy placówki zależna jest ilość dokumentów, jakie taka jednostka zawiera. Może to być nawet ok. $300 \mathrm{w}$ roku, ale też zdarzały się takie, gdy wydawany był jeden miesięcznie. Jednostki wchodzące w skład grupy oznaczane są literą „R” i kolejną liczbą arabską. Do rozpoczęcia zeszłorocznych prac Instytut posiadał 1766 jednostek rozkazów. Nieduża ich część jest zeskanowana i udostępniona przez stronę internetową Instytutu ${ }^{1}$.

Akta do porządkowania pozyskiwane były z materiałów przekazanych przez Anglików, nieuporządkowanych jeszcze i niewłączonych do zasobu. Akta te oznaczone były na pudłach roboczymi cyframi „X”, „Y”, ,Z”. W trakcie relacjonowanego wyjazdu sprawdzono oraz opracowano rozkazy z pudeł grupy oznaczonej literą „Y” i część z grupy „Z” (rozkazy z pudeł „X” zostały już wcześniej opracowane). Pozostało po pracach 6 pudeł „X” i 14 ,Y”, z tym że nie ma już w nich rozkazów, a inna dokumentacja archiwalna. Natomiast w pozostałych jeszcze 86 (ok. $11 \mathrm{mb}$ ) pudłach nieuporządkowanych materiałów oznaczonych „Z” są jeszcze niewłączone rozkazy. Zakończenie ich porządkowania to kolejny, finalny cel prac dla tej grupy akt.

Prace porządkujące wykonywane były według już wypróbowanego schematu. Na początku wyselekcjonowano i identyfikowano akta. Następnie konieczne było sprawdzenie, czy odnalezione dokumenty już znajdują się w zasobie. Jeżeli takie już były, usuwano z nich elementy metalowe, układano, pakowano w obwolutę i spisywano jako dublet. W przypadku nieodnalezienia w katalogach informacji, że takie rozkazy są już w zasobie, należało przygotować je do włączenia. Pierwszą czynnością było, jak zawsze, pozbawianie akt wszelkich elementów metalowych, następnie układano w kolejności (według numerów rozkazów) poszczególne dokumenty. Jednostki archiwalne formowano, przyjmując, że jeden rok to osobna jednostka dla poszczególnych oddziałów i placówek. Nawet jeżeli odna-

${ }^{1}$ Strona Instytutu Polskiego i Muzeum im. gen. Sikorskiego http://www.pism.co.uk/dokumenty_ r1.htm (odczyt: 22.01.2018). 
leziony został jeden dokument (rozkaz) z danego roku, powstawała z niego nowa jednostka. Wyjątkiem od tej zasady była tylko sytuacja, gdy odnalezione rozkazy były już oprawione, wtedy cały taki tom stawał się jedna jednostką. Na koniec opisywano obwoluty, wpisywano do ewidencji i pakowano w pudła. Były też sytuacje, że z porządkowanych akt należało włączyć tylko część, dotychczas brakującą. W takich przypadkach żmudnie dołączano brakujące numery (czy nawet pojedyncze rozkazy) do jednostki i oczywiście korygowano ewidencję. Jeżeli włączyć przypadło do już zeskanowanej jednostki - to w tym przypadku formowana była nowa jednostka.

Łącznie w trakcie opisywanego wyjazdu udało się opracować i włączyć 126 jednostek archiwalnych (liczących 3,3 mb) - sygn. R.1767 do R.1892. Oprócz akt włączonych do zasobu, kolejne $2 \mathrm{mb}$ wyłączone zostały jako dublety. Archiwalia zachowały się na ogół w dobrym stanie, ale osiem jednostek było zagrzybionych i zostały odseparowane.

Wśród włączonych jednostek wyróżnia się zwłaszcza znaczna ilość akt szpitali i ośrodków leczniczo-rehabilitacyjnych. Ich siatka daje pewne wyobrażenie o potrzebach wojska nie tylko ważne były jednostki bojowe i poligony, ale też obiekty i instytucje zabezpieczające byt i zdrowie żołnierzy. Odnaleziono też i włączono komplet rozkazów Biura Cenzury Rachunkowej Naczelnego Dowództwa (MON). Ta mieszcząca się w Glasgow komórka zajmowała się nadzorem nad budżetem wojska, kontrolowała wydatki jednostek czy nadzorowała przekazywane przez sojuszników środki finansowe. Dużo porządkowanych akt pochodzi już z okresu po zakończeniu działań wojennych i dlatego zwracają uwagę rozkazy różnych obozów rozdzielczych czy przesiedleńczych, przez które przewijały się masy migrantów (jako załączniki dołączane były listy przybywających i opuszczających obozy).

Łącznie w ciągu czterech miesięcy pracy (wyjazdy w 2016 i 2017) zasób „Rozkazów” zwiększył się o prawie jedną czwartą. 